ISSN: 2362-1303 (Paper) | eISSN: 2362-1311(Online)

JOURNAL OF ADVANCED ACADEMIC RESEARCH (JAAR) April 2017

\title{
Binary Opposition of Eros and Thanatos in Wordsworth's "The Rainbow"
}

Vijay Kumar Datta ${ }^{1} \&$ Beerendra Pandey ${ }^{2}$

${ }^{1} \mathrm{PhD}$ Scholar, Mewar University, Chittorgarh, Rajasthan, India

${ }^{2}$ Research Supervisor, Professor, Tribhuvan University, Kirtipur.

Corresponding Author

Vijay Kumar Datta

Email: vijay.dutta2011@gmail.com

\begin{abstract}
William Wordsworth's most quintessential, oeuvre-defining ode-“The Rainbow"-is unjustifiably under-commented in literary criticisms on the British Romantic poet. Plugging this critical gap, an attempt has been made to make a full-fledged critical analysis of the dynamics of the Freudian concepts of eros and thanatos in the poem. This analysis has been undertaken to make the argument that the dialectical play, which is finally resolved in favour of life-drive, helps sustain the poet's life-long joyful communion with Nature, despite the threats of trauma and tentativeness to bog him down.
\end{abstract}

\section{KEYWORDS}

Wordsworth, “The Rainbow”, Freud, Eros, Thanatos, Trauma

\section{INTRODUCTION}

William Wordsworth's short, lyrical ode "The Rainbow" occupies both a central position in anthologies but a relatively peripheral treatment in much of Wordsworthian criticism. Although it figures regularly in textbook anthologies and British Romantic readings, there are a few fullfledged critical treatments of the poem. Much of the Wordsworthian criticism treats it slightly with reference to the critical discussion of the poet's "Ode, Intimations of Immortality," wherein the short ode's last three lines figure as epigraph to the longer poem. Joshua Wilner (2003: 21-22) attributes the short poem's critical "centrality" to the remarks of Frances Ferguson and F. W. Bateson that "in all the editions of Wordsworth's collected poems that he supervised it is the opening poem and also by its hold on the public memory." While handing out a comprehensive, critical treatment to the short ode, Wilner focuses on "the sacramental aspects of the poem" in order to argue that the text "seems to naturalize the supernatural and to internalize the transcendent, subsuming inherited religious ideas and patterns within a secular outlook" (22). Another critic giving a religious interpretation of the poem is Bruce Ross (2000: 135-36) who takes the "symbolism of the rainbow" as "reverential appreciation found in the Hebrew rainbow prayer" and "the spiritualization of beauty."

In divergence with the above critical verdicts, this article argues, by means of a historical contextualization and a structuralist reading of Sigmund Freud's concept of eros and thanatos of 
ISSN: 2362-1303 (Paper) | eISSN: 2362-1311(Online)

\section{JOURNAL OF ADVANCED ACADEMIC RESEARCH (JAAR) April 2017}

Wordsworth's "The Rainbow" that the ode dramatizes the binary opposition between the two Freudian concepts in the poem, with a final privileging of the former over the latter. Thought remarkably short, it acts as a preamble to his much-discussed longer poems including The Tintern Abbey, and in this sense, it comes out as a quintessential Wordsworthian poem.

\section{CONTEXTUALIZATION \& METHODOLOGY}

Fred Manning Smith (1935: 226-27) writes that William Wordsworth wrote "The Rainbow" on March 26, 1802 and he quotes both Dorothy Wordsworth who says that "on March 27 'William wrote part of an ode [Intimations of Immortality]" and Harper who informs his readers that "The ode was probably conceived immediately after he had [Wordsworth] had written the nine lines which are its germ, and of which he used the last three lines as its motto." Kenneth Lincoln (1972: 214) adds that Wordsworth "placed this short poem at the beginning of his 1815 collected poems and the Ode at the end." Throwing further light on Wordsworth's psychological condition in 1802, Smith adds:

Wordsworth was then doing some of his best work; he had entered upon what has been called his 'second period of productive energy.' Furthermore, he was carrying on a courtship with Mary Hutchinson, which was to end during the year in a marriage that 'completed the circle of his felicity.' All was well with Wordsworth in the spring of 1802. (229)

This joyful period in Wordsworth is preceded by the trauma of the premature death of his parents (when he was still an adolescent) and the dashing of his hopes from the French Revolution. In the period in between 1798 and 1799 when he wrote The Tintern Abbey and The Prelude, he was trying to transcend the trauma. In this regard, Paul Fry (2008: 183) asserts that in "The Rainbow" of 1802 "there is the same continuity between Before and After, masked by the rhetoric of transcendence, that there is in "Tintern Abbey." Taking a cue from the above contextualization, it is assumed that even though Wordsworth wrote the nine-liner ode when he was going through a cheerful phase in his life, the shadows of the trauma were still bothering him and that through its composition the poet is attempting at transcendence through a dialectical tension between eros and thanatos.

The theoretical framework chosen for textual analysis is a mélange of psychotherapy of trauma and the structuralist theory of binary opposition. Psychotherapy concerns itself with the trauma and the death drive that cause people to be dejected. Failure to come to terms with it may lead to neurotic suffering and suicidal tendency. As Anthony Bateman, et. al. (2000: 33) state, psychotherapy, by activating the life-drive, help overcome "conflict and breakdown" and "promote and channel a drive towards cooperation and cohesion in both individuals and societies." Lois Tyson (2006: 24) attributes life-drive and death-drive respectively to Freudian "eros" [love/sex, life) and "thanatos [depression/decay/death]" Summarizing Freud, Babs Barron (2012: 9) makes a distinction between these two instinctual drives as follows:

Eros inspires us to strive for individual happiness and informs our wishes to unite with others. It drives living organisms to develop. Thanatos, on the 
ISSN: 2362-1303 (Paper) | eISSN: 2362-1311(Online)

\section{JOURNAL OF ADVANCED ACADEMIC RESEARCH (JAAR) April 2017}

other hand, represents decay, and drives the organism toward a return to the inorganic, to death. Freud posits that these two forces are in conflict with one another and that this conflict and interaction determines the development of the individual's life.

Freud, as Barron summarizes him, seems to posit the two instinctual drives in binary opposition to each other. Binary opposition is a key concept of structuralism, which sees such a binary distinction as fundamental to life and letters but one pole in the opposition valorized over the other pole. About the privileging of eros over thanatos, Barron observes:

In most mature people, Eros is able to override Thanatos for the majority of the time, or at least there is a balance between the two which makes life comfortable, even fulfilling. Such people have developed sufficiently to be able to make a synthesis between the two, which translates into how they interact with and relate to others in the wider society. However, this requires cognitive and emotional maturity and the capability to tolerate a degree of frustration and uncertainty until that synthesis is complete. (9)

This article argues that Wordsworth's "The Rainbow" makes a healthy synthesis between eros and thanatos.

\section{DISCUSSION AND ANALYSIS}

The dialectic of joy and dejection is a persistent theme in Wordsworth's major poetry. He remains very conscious of a highly tantalizing, celebratory Nature even when contemplates very bleak and glum possibilities for mankind. This dialectical tension between the drives of life and death is quite accentuated in "The Rainbow," which is of mere nine lines:

My heart leaps up when I behold

A Rainbow in the sky:

So was it when my life began;

So is it now I am a Man;

So be it when I shall grow old,

Or let me die!

The Child is Father of the Man;

And I could wish my days to be

Bound each to each by natural piety.

The poem begins on a note of the momentum of eros as the poet exultantly marvels at the beauty of Nature - the rainbow — which makes him almost sexually excited - "my heart leaps up." As Brennan O'Donnell (1995: 36) points out, the dynamic verb, "placed significantly in an offbeat position, ... dislocates the verse," thereby striking the readers as a deliberate defamiliarization, "and contribut[ing] to ... [an] expressive force" of love and sex as an adolescent and young man. The accelerating momentum is suddenly slowed down considerably when he tentatively wishes his old days to be equally sexually exciting — "So be it when I shall grow old." The uncertainty gives way to thanatos as he does not see the point of living at all if Nature were not tantalizing any 
ISSN: 2362-1303 (Paper) | eISSN: 2362-1311(Online)

\section{JOURNAL OF ADVANCED ACADEMIC RESEARCH (JAAR) April 2017}

longer-“"Or let me die!" According to Lincoln (214), the death-wish — a "heavily accented and shrilly dramatic proclamation" — runs counter to the tone and temper of the aphorism—- "The Child is the Father of the Man" which jolts the poet back from the sagging state of thanatos to the vibrant energy of eros. This rebounding of eros after a spate of thanatos, however, makes him aware of the power of ravaging temporality and the limitations of doddering age so that the wishful affirmation of the continuity of his the poet's love for Nature in the last two lines cannot mask the significant alternation in the nature of love - from the sexual, carnal to the spiritual, transcendental: the acting out of the progression from the teen-ager's leaping heart to an old man's devout affection for Nature. The continuity of the poet's love for Nature, thought altered significantly, unequivocally points to transcendence of the unsettling trauma and the lurking uncertainty.

\section{CONCLUSIONS}

Summing up, "The Rainbow" through a dramatization of the conflict between eros and thanatos plays out Wordsworth's struggles to successfully come out of the depressing moments for a lifelong relationship with Nature - a communion which begins on a carnal, sexual note but culminates into a spiritual union. The textual staging of the binary opposition in terms of the memory of childhood and manhood vis-à-vis the insecurity of oldhood demonstrates how the interplay of the two psychological drives can generate a meaningful participation in the beauty of Nature, in spite of the ravages of the ever-changing time.

\section{REFERENCES}

Barron, Babs. (2012) Eros and thanatos and the perpetuation of the Israel-Palestine conflict. Jewish Affairs;Chanukah 67 (3), 9-10

Bateman, Anthony. et. al. (2000). Introduction to psychotherapy: an outline of psychodynamic principles and practice. London: Routledge.

Fry, Paul H. (2008). Wordsworth and the poetry of what we are. New Haven: Yale University Press.

Lincoln, Kenneth R. (1972). Wordsworth's mortality ode. The Journal of English and Germanic Philology, 71 (2), 211-225.

O'Donnell, Brennan. (1995). The passion of meter: a study of Wordsworth's metrical art. Kent, Ohio: Kent State University Press.

Ross, Bruce. (2000). Wordsworth's rainbow and ours: a kabbalist understanding of beauty." In Anna-Teresa Tymieniecka's (Ed.), The poetry of life in literature (pp. 135-148). Dordrecht: Kluwer Academic Publishers.

Smith, Fred M. (1935). The relation of Coleridge's Ode on Dejection to Wordsworth's Ode on Intimations of Immortality. PMLA, 50 (1), 224-234.

Tyson, Lois. Critical theory today: a user-friendly guide. London: Routledge.

Wilner, Joshua. (2003). Feeding on infinity: readings in the romantic rhetoric of internalization. Baltimore: Johns Hopkins University Press. 
ISSN: 2362-1303 (Paper) | eISSN: 2362-1311(Online)

JOURNAL OF ADVANCED ACADEMIC RESEARCH (JAAR) April 2017

Wordsworth, William. (1919). The rainbow. In Arthur Quiller-Couch's, (Ed), The Oxford book of English verse: $1250-1900$. http://www.bartleby.com/101/532.html 